\title{
CONDITION AND PROBLEMS OF ENTREPRENEURIAL SUBJECTS LENDING
}

\author{
Olha Chernenko ${ }^{1}$ \\ chernenko.olha.s@ukr.net \\ Iryna Vdovenko \\ ira_vdovenko@i.ua \\ ${ }^{1}$ National Research Center "Institute of Agrarian Economics" \\ 10 Heroiv Oborony str., Kyiv, Ukraine, 03127
}

\begin{abstract}
Lending is a main instrument of bank institutions' influence on the development of economy and its subjects. The aim of the paper is to analyze the condition of entrepreneurial subjects lending by the bank system, especially agrarian enterprises, and separation of main restraining factors of its development. During 2017-2020 there is observed an essential reduction of volumes of medium-term and long-term credits, given to entrepreneurial subjects. The use of short-term credits for less than 1 year, the most specific weight $(80.5 \%)$ of which is possessed by microentrepreneurial subjects with annual income less than 50 thousand euro, prevails. It has been established, that high cost of credit resources, absence of correspondent guarantee and insufficient competitiveness of most entrepreneurial subjects prevent the development of credit relations for all participants (borrowers, creditors and state).

Agricultural economy that produces more than $12 \%$ of GDP and provides more than $40 \%$ of Ukrainian currency receipts, demonstrates positive financial results of activity, is really underfinanced at the expanse of bank credits. A share of credits, directed to the agrarian sector during last years, is essentially less than the contribution of the branch in the gross added value formation in the country. A bank credit policy, acceptable for all entrepreneurial subjects and directed on credit cost decrease and long-term lending increase, is necessary. Studies of the influence of arrangements in the AIC by reduction of credit prices on effective indices (pure profit of agrarian enterprises) has testified a close connection $(\mathrm{R}=0,9803)$, comparing with other factors, that is why the practice of using the preferential lending mechanism must be continued, but by stable, not continuously changing approaches and by direct state support of just small and medium entrepreneurial subjects, which are most limited in access to credit resources of bank institutions.
\end{abstract}

Keywords: lending, microenterprise, small, medium and large entrepreneurial subjects, agrarian sector of economy, bank institution, bank credit, interest rate, preferential lending.

DOI: $10.21303 / 2504-5571.2021 .001731$

\section{Introduction}

The development of credit activity of bank institutions must be a key element of economic growth that has the direct influence on state sovereignty support and realization of its national interests under conditions of globalization processes [1].

Credit support of the real sector of economy by bank institutions is an important impulse for augmenting production volumes, its effective development, financial potential growth, increase of their competitiveness and achievement of strategic goals of all economic subjects, especially enterprises of the agrarian economic sector with specific branch peculiarities of business realization.

The most widespread and available organizational forms of economic activity in the world practice are small and medium entrepreneurial subjects, which activation conditions the progress of modern society and is a sign of growing economy of the market type under conditions of globalization processes intensification and their influence on bank lending of such subjects.

Thus, economic sources [2] underline the role of "global diversification in determining both price and credit condition price and show that its advantages exceed costs and generate more favorable credit conditions". The authors also studied "the effect of globalization as to the term of a credit and requirements to guarantee" that improves financial relations between a creditor and 
a borrower. Conclusions as to "the lag of bank system globalization from one of non-financial companies" have been made, corporative globalization also offers banks an economically effective way to diversify their loan portfolios at the international level, because "such diversification can increase bank tolerance to each credit and to decrease risk acceptance cost, resulting in more stimulus for banks to realize monitoring functions".

A precondition for successful functioning of entrepreneurial subjects is free access to financial resources, it especially concerns small and medium ones, most limited in access to credit institutions' resources [3-6] because of certain restrain factors.

It has been also established, that "the level of access of International financial organizations to small and medium enterprises lending is low (41.7 \%) and fear of refusal of demand and small sums of credit explain this conclusion" [3].

One of restraining factors of small and medium entrepreneurial subjects lending by bank institutions is the absence of a reliable mortgage, which "can provide better protection to a borrower" and "is connected with longer terms of credit lines repayment" [7].

In the last years there appeared a lending with the equal level (P2P), supported by the internet, as an alternative to bank lending. In the global scale, P2P lending regulation essentially changed in the last years that formed mainly favorable results for diversification of private persons and corporations financing. We describe and assess the assortment of P2P lending systems, offered to small and medium enterprises (SME) in several countries, taking into account different regulation regimes. $\mathrm{P} 2 \mathrm{P}$ lending platforms provide the Internet-market to correspondent investors that want to credit borrowers, searching for credits, eliminating the necessity for banks to be mediators. Natural persons or enterprises can be borrowers [8]. So, limitations in access of small and medium entrepreneurial subjects to credit resources need improvement of bank lending mechanisms and search for ways for improving financial support of their entrepreneurial activity that is the research aim.

The aim of the paper is to analyze the condition of entrepreneurial subjects lending by the bank system, especially agrarian enterprises, and separation of problems, restraining the development of credit relations.

\section{Materials and methods}

The research is based on main principles of economic theory and one of finances, scientific works of Ukrainian and foreign scientists on problem questions of entrepreneurial subjects lending. For realizing the set research aim, the following methods and techniques were used: monographic for detail study of the lending condition of entrepreneurial subjects, enterprises of the agrarian sector of economy and legislative acts and regulations on questions of preferential lending mechanism introduction; analysis and synthesis - for detailing the research object; comparison - for juxtaposing factual data (credit volumes and costs) in different time periods for revealing causative connections; correlation-regression analysis - for assessing internal and external causal connections between factors, creating a model and for establishing functioning regularities and development tendencies of a studied resulting sign (influence of arrangements in the agroindustrial complex on pure profit of agrarian enterprises by reducing credit prices) that gave a possibility to make conclusions as to the necessity to elongate a preferential lending program; generalization - at elaborating proposals as to entrepreneurial subjects lending improvement, development of enterprises in the agrarian branch.

\section{Research results}

The most essential restraining or stimulating factor for expanding volumes of entrepreneurial subjects lending by bank institutions is a cost of credits themselves (Table 1).

Analyzing the cost of credits, given to economic subjects in Ukraine (Table 1), it can be noted, that it is higher in 2.3 times in national currency (average value for 2017-2020 is 16.9\%), comparing with the credit cost in foreign currency (the average value for the same period is $7.2 \%$ ). At that the cost of short-term credits in national currency (average value for $2017-2020$ is $16.8 \%$ 
per annum, and long-term - $16.1 \%$ ). The cost of short-term credits in foreign currency is $8.2 \%$, and long-term $-7.1 \%$ respectively.

Table 1

Dynamics of credit cost for economic subjects (average weighted), \% [9]

\begin{tabular}{cccccc}
\hline Parameters & $\mathbf{2 0 1 7}$ & $\mathbf{2 0 1 8}$ & $\mathbf{2 0 1 9}$ & $\mathbf{2 0 2 0}$ & Deviation 2019 to 2017 (+;-) \\
\hline 1. In Ukrainian hryvnya - totally & 17.7 & 20.0 & 15.2 & 14.5 & $-3.2 \mathrm{pp}$ \\
- Short-term & 18.7 & 19.7 & 13.9 & 14.9 & $-3.8 \mathrm{pp}$ \\
- Long-term & 15.8 & 20.5 & 13.9 & 14.1 & $-1.7 \mathrm{pp}$ \\
2. In foreign currency (in euro) & 8.8 & 6.5 & 5.3 & 8.2 & $-0.6 \mathrm{pp}$ \\
- Short-term & 10.2 & 5.5 & 8.4 & 8.5 & $-1.7 \mathrm{pp}$ \\
- Long-term & 8.9 & 9.0 & 4.7 & 5.8 & $-3.1 \mathrm{pp}$
\end{tabular}

The studies have established that the penetration level of gross credits for economic subjects to GDP had shortened from $51.7 \%$ in 2014 to $25.8 \%$ in 2018 , and the one of pure ones - from $44.7 \%$ in 2014 to $13.3 \%$ in 2018 .

Depending on economic subjects' sizes, volumes of given credits differ by repayment terms (Table 2).

Table 2

Dynamics of credits, given to economic subjects by sizes and repayment terms [9]

\begin{tabular}{|c|c|c|c|c|}
\hline Parameters & 2017 & 2018 & 2019 & 2020 \\
\hline 1 & 2 & 3 & 4 & 5 \\
\hline \multicolumn{5}{|c|}{ By terms, mln euro: } \\
\hline Less than 1 year & 10724.7 & 12968.5 & 13952.6 & 10747.3 \\
\hline $1-5$ years & 8729.6 & 8718.7 & 8751.8 & 6747.4 \\
\hline More than 5 years & 5619.1 & 5263.9 & 4977.7 & 3434.7 \\
\hline \multicolumn{5}{|c|}{ By subject size: } \\
\hline $\begin{array}{l}\text { Large entrepreneurial subjects, } \\
\text { Totally, mln euro }\end{array}$ & $\begin{array}{l}9394.2 \\
(100 \%)\end{array}$ & $\begin{array}{c}9719.9 \\
(100 \%)\end{array}$ & $\begin{array}{l}8723.3 \\
(100 \%)\end{array}$ & $\begin{array}{c}6382.6 \\
(100 \%)\end{array}$ \\
\hline Less than 1 year & $\begin{array}{c}4059.8 \\
(43.2 \%)\end{array}$ & $\begin{array}{c}5074.8 \\
(52.2 \%)\end{array}$ & $\begin{array}{c}4816.5 \\
(55.2 \%)\end{array}$ & $\begin{array}{c}3037.1 \\
(47.6 \%)\end{array}$ \\
\hline $1-5$ years & $\begin{array}{c}3622.4 \\
(38.6 \%)\end{array}$ & $\begin{array}{c}3540.7 \\
(36.4 \%)\end{array}$ & $\begin{array}{c}2924.6 \\
(33.5 \%)\end{array}$ & $\begin{array}{c}2470.8 \\
(38.7 \%)\end{array}$ \\
\hline More than 5 years & $\begin{array}{c}1712.0 \\
(18.2 \%)\end{array}$ & $\begin{array}{l}1104.5 \\
(11.4 \%)\end{array}$ & $\begin{array}{c}982.3 \\
(11.3 \%)\end{array}$ & $\begin{array}{c}874.7 \\
(13.7 \%)\end{array}$ \\
\hline $\begin{array}{l}\text { Medium entrepreneurial subjects, } \\
\text { Totally, mln euro }\end{array}$ & $\begin{array}{c}6329.9 \\
(100 \%)\end{array}$ & $\begin{array}{c}6661.1 \\
(100 \%)\end{array}$ & $\begin{array}{c}6869.3 \\
(100 \%)\end{array}$ & $\begin{array}{c}6183.8 \\
(100 \%)\end{array}$ \\
\hline Less than 1 year & $\begin{array}{c}2581.5 \\
(40.8 \%)\end{array}$ & $\begin{array}{c}3219.0 \\
(48.3 \%)\end{array}$ & $\begin{array}{c}2942.2 \\
(42.8 \%)\end{array}$ & $\begin{array}{c}3193.6 \\
(51.6 \%)\end{array}$ \\
\hline $1-5$ years & $\begin{array}{c}2398.1 \\
(37.9 \%)\end{array}$ & $\begin{array}{l}2124.8 \\
(31.9 \%)\end{array}$ & $\begin{array}{c}2385.0 \\
(34.7 \%)\end{array}$ & $\begin{array}{c}1881.5 \\
(30.4 \%)\end{array}$ \\
\hline More than 5 years & $\begin{array}{c}1350.2 \\
(21.3 \%)\end{array}$ & $\begin{array}{c}1317.3 \\
(19.8 \%)\end{array}$ & $\begin{array}{c}1542.0 \\
(22.4 \%)\end{array}$ & $\begin{array}{c}1108.7 \\
(17.9 \%)\end{array}$ \\
\hline $\begin{array}{l}\text { Small entrepreneurial subjects, } \\
\text { Totally, mln euro }\end{array}$ & $\begin{array}{c}3355.1 \\
(100 \%)\end{array}$ & $\begin{array}{l}2961.6 \\
(100 \%)\end{array}$ & $\begin{array}{c}2743.8 \\
(100 \%)\end{array}$ & $\begin{array}{c}2027.0 \\
(100 \%)\end{array}$ \\
\hline Less than 1 year & $\begin{array}{c}1403.9 \\
(41.8 \%)\end{array}$ & $\begin{array}{c}1233.4 \\
(41.6 \%)\end{array}$ & $\begin{array}{c}1019.4 \\
(37.2 \%)\end{array}$ & $\begin{array}{c}719.7 \\
(35.5 \%)\end{array}$ \\
\hline $1-5$ years & $\begin{array}{c}1122.7 \\
(33.5 \%)\end{array}$ & $\begin{array}{c}946.4 \\
(31.9 \%)\end{array}$ & $\begin{array}{c}1010.0 \\
(36.8 \%)\end{array}$ & $\begin{array}{c}720.5 \\
(35.5 \%)\end{array}$ \\
\hline
\end{tabular}


Continuation of Table 2

\begin{tabular}{|c|c|c|c|c|}
\hline 1 & 2 & 3 & 4 & 5 \\
\hline More than 5 years & $\begin{array}{c}828.5 \\
(24.7 \%)\end{array}$ & $\begin{array}{c}782.2 \\
(26.4 \%)\end{array}$ & $\begin{array}{c}714.3 \\
(26.0 \%)\end{array}$ & $\begin{array}{c}586.8 \\
(28.9 \%)\end{array}$ \\
\hline Microentrepreneurial subjects & \multicolumn{4}{|c|}{ Annual income from 500 thousand euro to $2 \mathrm{mln}$ euro } \\
\hline Totally, mln euro & $\begin{array}{c}881.8 \\
(100 \%)\end{array}$ & $\begin{array}{c}922.5 \\
(100 \%)\end{array}$ & $\begin{array}{c}1658.9 \\
(100 \%)\end{array}$ & $\begin{array}{c}1330.2 \\
(100 \%)\end{array}$ \\
\hline Less than 1 year & $\begin{array}{c}215.4 \\
(24.4 \%)\end{array}$ & $\begin{array}{c}275.8 \\
(29.9 \%)\end{array}$ & $\begin{array}{c}814.9 \\
(49.1 \%)\end{array}$ & $\begin{array}{c}673.8 \\
(50.7 \%)\end{array}$ \\
\hline $1-5$ years & $\begin{array}{c}342.5 \\
(38.8 \%)\end{array}$ & $\begin{array}{c}348.2 \\
(37.7 \%)\end{array}$ & $\begin{array}{c}435.2 \\
(26.2 \%)\end{array}$ & $\begin{array}{c}353.1 \\
(26.5 \%)\end{array}$ \\
\hline More than 5 years & $\begin{array}{c}323.8 \\
(36.7 \%)\end{array}$ & $\begin{array}{c}298.4 \\
(32.4 \%)\end{array}$ & $\begin{array}{c}408.8 \\
(24.6 \%)\end{array}$ & $\begin{array}{c}303.3 \\
(22.8 \%)\end{array}$ \\
\hline Microentrepreneurial subjects & \multicolumn{4}{|c|}{$\begin{array}{c}\text { Annual income from } 50 \text { thousand euro to } 500 \text { thousand } \\
\text { euro }\end{array}$} \\
\hline Totally, mln euro & $\begin{array}{c}505.6 \\
(100 \%)\end{array}$ & $\begin{array}{c}859.8 \\
(100 \%)\end{array}$ & $\begin{array}{c}1651.3 \\
(100 \%)\end{array}$ & $\begin{array}{c}1223.7 \\
(100 \%)\end{array}$ \\
\hline Less than 1 year & $\begin{array}{c}153.1 \\
(30.3 \%)\end{array}$ & $\begin{array}{c}163.3 \\
(18.9 \%)\end{array}$ & $\begin{array}{c}738.3 \\
(44.7 \%)\end{array}$ & $\begin{array}{c}559.2 \\
(45.7 \%)\end{array}$ \\
\hline $1-5$ years & $\begin{array}{c}211.9 \\
(41.9 \%)\end{array}$ & $\begin{array}{c}558.2 \\
(64.9 \%)\end{array}$ & $\begin{array}{c}677.5 \\
(41.0 \%)\end{array}$ & $\begin{array}{c}523.9 \\
(42.8 \%)\end{array}$ \\
\hline More than 5 years & $\begin{array}{c}140.6 \\
(27.8 \%)\end{array}$ & $\begin{array}{c}138.3 \\
(16.1 \%)\end{array}$ & $\begin{array}{c}235.4 \\
(14.3 \%)\end{array}$ & $\begin{array}{c}140.6 \\
(11.5 \%)\end{array}$ \\
\hline Microentrepreneurial subjects & \multicolumn{4}{|c|}{ Annual income less than 50 thousand euro } \\
\hline Totally, mln euro & $\begin{array}{l}2024.7 \\
(100 \%)\end{array}$ & $\begin{array}{c}2271.7 \\
(100 \%)\end{array}$ & $\begin{array}{c}2842.2 \\
(100 \%)\end{array}$ & $\begin{array}{l}2091.0 \\
(100 \%)\end{array}$ \\
\hline Less than 1 year & $\begin{array}{c}1570.4 \\
(77.6 \%)\end{array}$ & $\begin{array}{c}1742.8 \\
(76.7 \%)\end{array}$ & $\begin{array}{c}2327.7 \\
(81.9 \%)\end{array}$ & $\begin{array}{c}1795.6 \\
(85.9 \%)\end{array}$ \\
\hline $1-5$ years & $\begin{array}{c}375.6 \\
(18.6 \%)\end{array}$ & $\begin{array}{c}370.1 \\
(16.3 \%)\end{array}$ & $\begin{array}{c}344.5 \\
(12.1 \%)\end{array}$ & $\begin{array}{c}235.3 \\
(11.3 \%)\end{array}$ \\
\hline More than 5 years & $\begin{array}{c}78.7 \\
(3.9 \%)\end{array}$ & $\begin{array}{c}158.9 \\
(6.9 \%)\end{array}$ & $\begin{array}{c}170.1 \\
(5.9 \%)\end{array}$ & $\begin{array}{c}60.1 \\
(2.9 \%)\end{array}$ \\
\hline
\end{tabular}

Thus, if volumes of short-term credits for less than 1 year, given to all economic subjects in 2017-2020, almost didn't change, ones of credits for 1-5 years and more than 5 years shortened in 1.3 and 1.6 times respectively. So, short-term lending of economic subjects, which growth volumes are unessential, prevails.

According to point 3 of article 55 of the Economic code of Ukraine [10], economic subjects may belong to small entrepreneurial subjects, including micro entrepreneurship, medium or large ones, depending on number of employees and incomes from any activity per annum.

Thus, microentrepreneurial subjects are natural persons, registered as regulated by law as natural persons - entrepreneurs and juridical persons - economic subjects of any organizational-legal and property form, whose average number of employees for the reporting period (calendar year) doesn't exceed 10 persons, and whose annual income doesn't exceed the sum, equivalent to 2 million euro, determined by the average annual rate of exchange of the National bank of Ukraine.

Small entrepreneurial subjects are: natural persons, registered as regulated by law as natural persons - entrepreneurs and juridical persons - economic subjects of any organizational-legal and 
property form, whose average number of employees for the reporting period (calendar year) doesn't exceed 50 persons, and whose annual income doesn't exceed the sum, equivalent to 10 million euro, determined by the average annual rate of exchange of the National bank of Ukraine.

According to the Ukrainian legislation, large entrepreneurial subjects are juridical perU sons - economic subjects of any organizational-legal and property form, whose average number of employees for the reporting period (calendar year) doesn't exceed 250 persons, and whose annual income doesn't exceed the sum, equivalent to 50 million euro, determined by the average annual rate of exchange of the National bank of Ukraine.

Analyzing the lending condition of economic subjects by their sizes, a conclusion can be made that during 2017-2020 rather essential reduction of lending volumes is observed in large, small entrepreneur2 ial subjects - in 1.5 and 1.7 times respectively. On the contrary, the essential growth of lending volumes is observed in microentrepreneurial subjects with the annual income from 500 thousand euro to $2 \mathrm{mln}$ euro (in 1.5 times) and with annual income from 50 thousand euro to 500 thousand euro (in 2.4 times).

As to terms of obtained credits in 2017-2020, there is a following tendency: the most part of credits of large, small and medium entrepreneurial subjects is short-term ones, which specific weight is $49.6 \%, 39 \%$ and $45.9 \%$ respectively.

Microentrepreneurial subjects with the annual income less than 50 thousand euro take the lion share $(80.5 \%)$ of short-term credits for less than 1 year, and the least share $(4.9 \%)$ is credits for more than 5 years.

So, during 2017-2020 there is observed the essential reduction of volumes of medium-term and long-term credits, given to entrepreneurial subjects. Among enterprises of different sizes, using credits, the use of short-term ones for less than 1 year, the most specific weight of which $(80.5 \%)$ is possessed by microentrepreneurial subjects with the annual income less than 50 thousand euro, prevails, although lending volumes for this period almost didn't change in them (have grown in 1,03 times).

As to lending of enterprises of the agrarian sector of economy, their share in the total volume of given credits for the analyzed period is only $6.4 \%$. Main restraining factors of agrarian enterprises lending may be considered from the side of a creditor and from a borrower (Fig. 1).

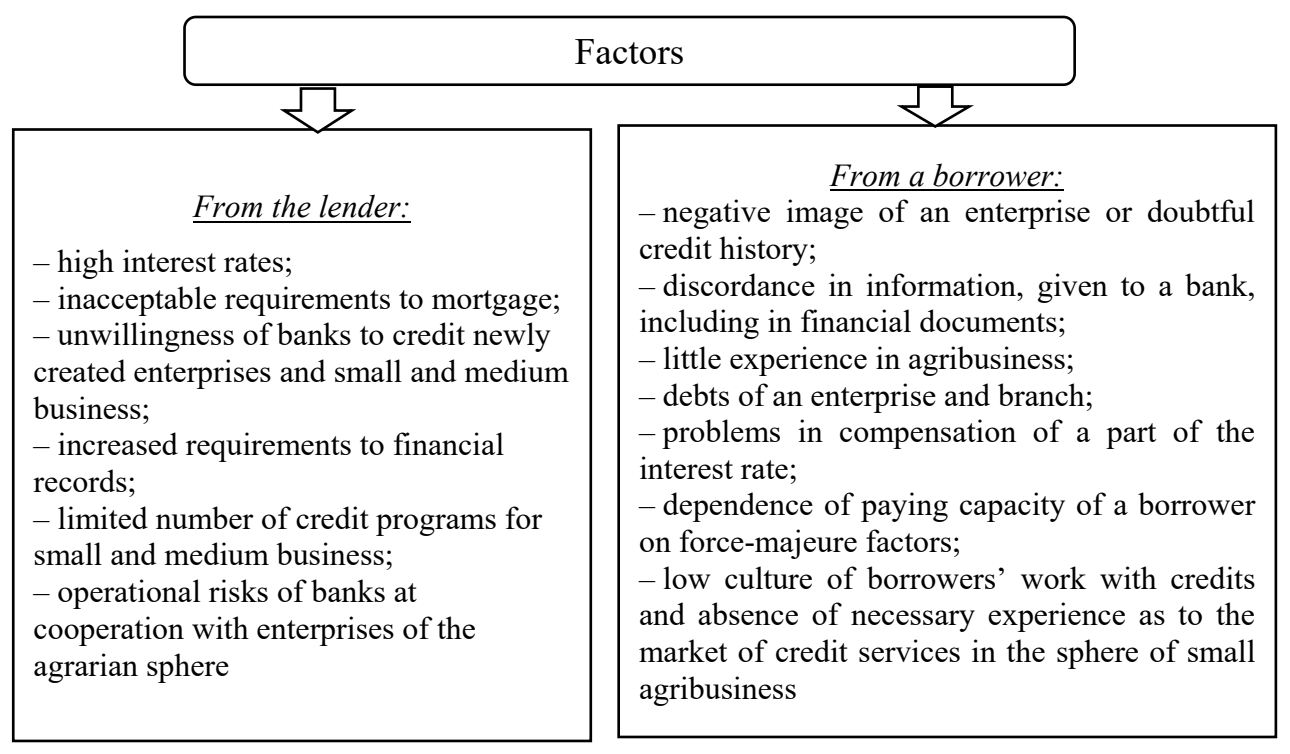

Fig. 1. Restraining factors for agrarian enterprises lending. Source: generalized by the author based on $[11,12]$

\section{Discussion}

At the same time the access of most agrarian enterprises to bank credits remains limited. The mechanism of preferential lending of commodity producers since 2000 was created in Ukraine as an effective mechanism of improving their accessibility for the branch, for decreasing the load 
on entrepreneurial subjects at paying interests for using credits, expanding their access to bank credits and decreasing their cost.

A negative feature of the existent mechanism is often changes of main statements of the actual legislation in the sphere of credit support of commodity producers (credit subsidy), especially in the part of: establishment of limitations as to interests for the use of credits, subject to price reduction, because of diversification of interest rates of commercial banks for using such credits; state support for AIC enterprises, then only for agricultural commodity producers; preferences for separate categories of borrowers (by realization volumes, activity types) at making decisions about giving a compensation; fixation of credit subsidy sizes (from the double accounting rate of NBU to $50 \%$ of the accounting rate of NBU); mechanism of costs direction by the program (on borrowers' operating accounts directly or through banks).

The main legislative document, regulating relations in the sphere of state financial support of the agroindustrial complex, especially by credit price reduction, is the Law of Ukraine "On state support of the Ukrainian agriculture", adopted in 2004 (article 13) [13]. During its existence, changes were intro $\theta$ duced to article 13, especially the mechanism of using costs, determined by orders of their use, changed: especially, in 2004-2006 compensation was given by credits for goals, determined for each category of borrowers, through competition commissions in regions, directly to banks (banks formed registers) that gave a credit, through regional administrations of the agroindustrial complex; in 2007-2009-costs were compensated through competition commissions in districts and regions on operating accounts of borrowers; in 2010-2012 - compensation was given through the competition commission of the Mine istry of agrarian policy on operating accounts of borrowers; in 2015-2018 compensation was already given by credits (without distribution in credit types) to all economic subjects of the agroindustrial complex. At making decision about giving compensation, a preference was given to small borrowers (pure income less than $10 \mathrm{mln}$ hrn) and ones, whose activity was connected with animal husbandry.

One more defect of the existent mechanism of preferential lending is lack of costs in the State budget, resulting in underfinancing of agrarian enterprises at the end of financial year. At the same time continuous changes of the circle of addressees of such support took place - from all enterprises of the agroindustrial complex in all branches of economy to small economic forms with annual realization volumes less than $20 \mathrm{mln}$ hrn.

Thus, in 2010-2012 state support addressees were AIC economic subjects, especially agrit cultural enterprises, ones of the fishing branch and separate categories of processing enterprises. Since 2015 the circle of addressees has narrowed only to agricultural commodity producers ber cause of cost deficit of the state budget for the program, and in 2017-2018 priority addressees of such subsidy were small economic forms.

The mechanism of costs distribution between regions of Ukraine remains the same during the whole period of the program - proportionally to the average annual production volume of all gross products of agriculture for previous 3 years before the reporting one. We think it doesn't take into account the real need of the regions in costs for reducing credit prices that results in excesses of unused costs in several regions and lack in other ones.

Credit types, that compensation was given by, also changed in this mechanism. Especially, in 2010-2012 compensation was given by short-, medium- and long-term credits, taken in both nae tional and foreign currency. In 2015-2017 compensation covered all credits, without a distribution in short-, medium- and long-term, taken only in national currency that gave economic subjects a possibility to determine directions of using credit costs. Correspondingly since 2018 because of lack of costs for the program, only short- and medium-term credits in national currency were subject to price reduction, with a limitation as to giving compensation only to borrowers with the pure income (receipts) from realization for the last year less than $20 \mathrm{mln} \mathrm{hrn}$.

Directions of credit costs use, according to which interest rate compensations were given, also changed depending on volumes of costs, provided by the State budget for this program and priority development directions, determined by the Government.

Despite the defects of the existent mechanism of preferential lending, the need of enterprises of the agrarian sector of economy in cheap credits whatever grows during the last years. Thus, 
during 2016-2018 the number of enterprises in Ukraine that used the program of credit price reducp tion grew twice, and credit volumes, subject to compensations, shortened in 1.4 times.

The total sum of credits, subject to compensation, during 2016-2018 - it is mainly shortterm credits for less than 1 year (64\%), as to directions of their use $-53.9 \%$ are costs in the plant cultivation branch, and interest rates of banks that economic subjects of the agrarian sector took preferential credits for were $15 \%-27.5 \%$.

The research of the correlation-regression dependence between financial support of arrangements in AIC by credit price reduction at pure profit of agrarian enterprises, described by the exponential function $y=20894 \mathrm{e}^{0,0049 x}$, has established the very close connection $\left(R^{2}=0,9803\right)$.

\section{Conclusions}

Thus, agriculture, producing more than $12 \%$ of GDP and providing more than $40 \%$ of currency receipts of Ukraine, demonstrates positive financial results of activity, is really underfinanced at the expanse of bank credits. The main source of its financing is own costs that are unessential and insufficient for self-financing by specific weight. The share of credits, directed in the agrarian sector during the last years, is much less than the contribution of this branch in the gross added value formation in Ukraine.

An important source of resources for all economic subjects in Ukraine must be credits of bank institutions with a credit policy, acceptable for enterprises (including agrarian ones). But lending remains too heavy instrument of costs involvement for many enterprises. High costs of credit resources, absence of correspondent mortgage and insufficient credit ability of most economic subjects interfere with the development of effective interrelations for all participants (borrowers, creditors and the state in whole). The research of the influence of arrangements in AIC by credit price reduction on resulting indices (pure profit of agrarian enterprises) has established the close connection $(R=0,9803)$, comparing with other factors, that is why the practice of using the preferential lending mechanism must be continued, but by stable, not continuously changing, approaches and direct state support of commodity producers - small and medium entrepreneurial subjects, most limited in access to credit resources of bank institutions. The necessity in state financial support of small commodity production subjects (including by free access to cheap credit resources) is caused by their ability to satisfy internal needs of the population of the country in food products and rural employment, to favor the development of rural territories and so on.

\section{References}

[1] Irshak, O. S., Leshchuk, I. Ya. (2018). Suchasnyi stan kredytnoi diialnosti bankiv ta yii vplyv na rozvytok realnoho sektoru ekonomiky. Prychornomorski ekonomichni studii, 34, 145-149.

[2] Li, S., Qiu, J., Wan, C. (2011). Corporate globalization and bank lending. Journal of International Business Studies, 42 (8), 1016-1042. doi: http://doi.org/10.1057/jibs.2011.29

[3] Wanambisi, A. N., Bwisa, P. H. M. (2013). Effects of Microfinance Lending on Business Performance: A Survey of Micro and Small Enterprises in Kitale Municipality, Kenya. International Journal of Academic Research in Business and Social Sciences, 3 (7). doi: http://doi.org/10.6007/ijarbss/v3-i7/9

[4] Rosemary, A. (2001). Formal and informal institutions' lending policies and access to credit by small-scale enterprises in Kenya: An empirical assessment By Rosemary Atieno University of Nairobi AERC Research Paper 111 African Economic Research Consortium. Nairobi,

[5] 5.Mazzoleni, A., Giacosa, E. (2017). Company's Indebtedness Trends in Small and Medium Sized Firms within the Company Systems Theory. International Journal of Business and Social Science, 8 (5), 69-75.

[6] Juszczyk, S., Jasionek, M. (2011). Kredytowanie sektora małych i średnich przedsiębiorstw w Polsce. Zeszyty Naukowe SGGW w Warszawie. Ekonomika i Organizacja Gospodarki Żywnościowej, 89, 219-228. Available at: http://sj.wne.sggw.pl/ pdf/EIOGZ_2011_n89_s219.pdf

[7] Ortiz-Molina, H., Penas, M. F. (2004). Lending to Small Businesses: The Role of Loan Maturity in Adressing Information Problems. (CentER Discussion Paper; Vol. 2004-99). Finance, 1-2. doi: http://doi.org/10.2139/ssrn.509882

[8] Naoko Nemoto, David J. Storey, Bihong Huang (2019). Optimal Regulation of P2P Lending for Small and Medium-Sized Enterprises. ADBI Working Paper 912. doi: http://doi.org/10.2139/ssrn.3313999

[9] Dani statystyky finansovoho sektoru. Available at: https://bank.gov.ua/ua/statistic/sector-financial/data-sector-financial\#1ms 
[10] Hospodarskyi kodeks Ukrainy (2003). Kodeks Ukrainy No. 436-IV. 16.01.2003. Available at: http://zakon.rada.gov.ua/laws/ show/436-15\#Text

[11] Lupenko, Yu. O., Andros, S. V. (2019). Bank lending to the agricultural economy sector. Economic Bulletin of National Technical University of Ukraine "Kyiv Polytechnical Institute", 16, 196-207. doi: http://doi.org/10.20535/2307-5651.16.2019.181851

[12] Vdovenko, L. O., Vdovenko, S. A. (2018). Stan ta perspektyvy rozvytku ahrarnoho sektoru v konteksti derzhavnoi polityky finansovoi pidtrymky tovarovyrobnykiv. Finansovo-kredytna diialnist: problemy teorii ta praktyky, 3, 113-122.

[13] Pro derzhavnu pidtrymku silskoho hospodarstva Ukrainy (2004). Zakon Ukrainy No. 1877-IV. 24.06.2004 Available at: https:// zakon.rada.gov.ua/laws/show/1877-15\#Text

How to cite. Chernenko, O., Vdovenko, I. (2021). Condition and problems of entrepreneurial subjects lending. EUREKA: Social and Humanities, 2, 3-10. doi: http://doi.org/10.21303/2504-5571.2021.001731 